\title{
In Defense of the Court's Legitimacy
}

\author{
John C. Yoo广
}

Even as it brought the 2000 presidential election to conclusion, Bush v Gore gave rise to a flurry of attacks on the legitimacy of the Supreme Court. Many scholars criticized the Court for its creation of a new Equal Protection Clause claim never before seen, for its sudden imposition of a deadline that foreclosed any remedy, for its apparent hypocrisy in intervening into a local election dispute, and for its intervention into an utterly partisan dispute. Criticism usually would come as no surprise-it is merely the standard discussion about the actions of the institution that is the focus of much of our work in academia.

While early opinion polls show that most Americans have decided to move on, it seems that many academic critics of Bush $v$ Gore have decided to go beyond the usual inulling over of Supreme Court opinions. In the weeks following the Court's decision, prominent legal acadermics have voiced a number of objections that question the Court's very legitimacy, and in some cases have urged the political systein to attack the Court. Many have characterized the decision as partisan and ungrolmded in law. Some have even compared the justices to partisan lobbyists. ${ }^{4}$ As a result, these critics have called upon the Senate to refuse to confirm any Supreme Court justices during President Bush's term, while others have hit upon the idea of reducing the number of justices on the Court. ${ }^{6}$ Soine have even gone so far as to compare the Court's alleged loss of legitimacy today to the Court's

+ Professor of Law, University of California at Berkeley School of Law (Boalt Hall). During the Florida election crisis, the author testified before a special committee of the Florida legislature concerning the state's options for choosing its presidential clectors 1 thank Jesse Choper and Phil Frickey for their comments.

1 Bush v Gore, 121 S Ct 525 (2000) (per curiam).

2 Even though a bare neajority of Americans initially agreed with the Court's ruling in Bush v Gore, 80 percent of respondents to a CNN/USA Today/Gallup poll conducted on Decenber 13,2000 , accepted Bush as the legitimate winner of the 2000 presidential election. David W. Moore, Eight in Ten Americans so Accept Bush as "Legitimate" President, Gallup News Service (Dec 14, 2000), available online at <http://www.gallup.com/poll/releases/pr001214.asp> (visited Feb 22, 2001).

3 See, for example, Akhil Amar, The Supreme Court: Should We Trust Indges?, LA Tinues M1 (Dec 17, 2000) ("[T]his is not the rule of law: It is the rule of subjective sensibility:").

4 See, for example, Bruce Ackerman, The Court Packs Itself. Am Prospect 48 (Feb 12, 2001), available online at <http//www.prospect.org/print/V12/3/ackerman-b.htmls (visited March 29, 2001).

5 See id.

6 Neal Katyal, Politics Over Principle, Wash Post A35 (Dec 14, 2000). 
decision in Dred Scott, with all of the dire consequences that it portended.'

Much of this enflamed rhetoric, while good for grabbing headlines, no doubt resulted from the heat of the moment rather than from careful reflection and thought. But even if this criticism is shallow, it is broad. At least 585 law professors took the unusual step of signing an ad published in the New York Times on January 13, 2001, decrying Bush $v$ Gore as an illegitinate, pohtical decision. ${ }^{8}$ The ad flatly declared: "when a bare majority of the U.S. Supreme Court halted the recount of ballots under Florida law, the five justices were acting as political proponents for candidate Bush, not as judges.""

Heady words. Such extraordinary criticism raises some questions worth pursuing. Did the Supreme Court somehow render an "illegitiinate" decision in Bush $v$ Gore? Has the Court undermined the institutional legitimacy that allows it to play a central role in American pohtics and society? What is the real threat to the Court's legitimacy in the aftermath of Bush $v$ Gore?

This Essay will argue that concerns about the Court's legitinacy are overblown. While it is certainly too early to be sure, the Court's actions, and their impact on the political system, come nowhere close to approaching the circumstances that surrounded earlier, real threats to the Court's standing. The Court did not decide any substantive issues - on a par with abortion or privacy rights, for example - that call upon the Court to remain continually at the center of political controversy for years. Instead, the Court issued a fairly narrow decision in a one-of-a-kind case-the procedures to govern presidential election counts - that is not likely to reappear in our lifetimes. Rather than acting hypocritically and lawlessly, the Court's decision to bring the Florida election dispute to a timely, and final, end not only restored stability to the pohtical system but was also consistent with the institutional role the Court has shaped for itself over the last decade.

\section{Legitimacy As Public Opinion}

Legitimacy is a word often used in our political debate, but seldoin defined precisely. We can think of institutional "legitinacy" as

\footnotetext{
7 Id, discussing Scott $v$ Sanford, 60 US 393 (1857).

8 On the problems with academics participating in such group letters or ads, see Neal Devins, Bearing False Witness: The Clinton Impeachment and the Future of Academic Freetom, 148 U Pa L Rev 165, 185-90 (1999) (warning of irrelevancy, loss of academic freedon, and reduced funding resulting from politically motivated letter writing).

9 Dave Zweifel, Court Decision Still Rankles Law Profs, Capital Times 6A (Jan 24, 2001) (reprinting text of ad).
} 
the belief in the binding nature of an institution's decisions, even when one disagrees with them. ${ }^{10}$ This sociological or even psychological definition of the term is concerned with whether people will think the Court's decision in Bush v Gore was legitimate, and as a result will obey it." It is different from philosophical legitimacy, in which one is concerned with moral obligations to follow the law. Our Weberian definition of legitimacy is also different than the manner in which Critical Legal Studies scholars use the phrase to argue that because the legal system is radically indeterminate, and produces unjust results, it is illegitimate. ${ }^{13}$

One way, then, to judge whether Bush v Gore has undermined the Court's institutional legitimacy in American society would be to examine public attitudes toward the Court. Studies have shown that public support for the Court and its role in society run high, even though inany liave little knowledge about the Court's day-to-day activities. ${ }^{14}$ While this is not the place to conduct a detailed study, we may perliaps draw some initial conclusions from recent Gallup polling data. Over the last decade, poll respondents have usually held more confidence in the Supreme Court than in the other two branches of government. ${ }^{16}$ In June 2000,47 percent of those polled said that they leld either a "great deal" or "quite a lot" of confidence in the Supreme Court, versus 42 percent for the presidency and 24 percent for Congress. ${ }^{17}$ Even in light of the usual caveats surrounding the use of polling data, the resiliency in the Court's public support has been relatively deep and wide, ${ }^{15}$ even as it has rendered a series of controversial

10 Legitimacy in this sense is composed of both a belief that an institution's command is obligatory, and an action in compliance. See Max Weber, 1 Economy and Society 31-33 (Bedminster 1968). See also Alan Hyde, The Concept of Legitimation in the Sociology of Law, 1983 Wise L Rev 379,381-82 (discussing Weber's analysis of "legitimacy").

11 See Toin R. Tyler and Gregory Mitchell, Legitimacy and the Emposrerment of Discretionary Legal Authority: The United States Supreme Court and Abortion Rights, 43 Duke L J 703, 711 n 25 (1994) (comparing sociological and philosophical notions of legitimacy).

12 See, for example, Ronald Dworkin, Law's Empire 190-215 (Belknap 1986); Joseph Raz, The Authority of Law: Essays on Law and Morality 1-27 (Clarendon 1979).

13 See Ken Kress, Legal Indeterninacy, 77 Cal L Rev 283, 285 (1989).

14 See, for example, Walter F. Murplyy and Joseph Tanenhaus, Publicity, Public Opinion, and the Court, 84 Nw U L Rev 985, 1019 (1990) ("[A]nalyses show there is no necessary conneetion between knowledge and support for the Court.").

is Political scientists have conducted several excellent studies about the relationship between public opinion and the Supreme Court. See, for example, Thomas R. Marshall, Public Opinion and the Supreme Court (Unwin Hyman 1989); Gregory A. Caldeirs, Public Opinion and the U.S Supreme Court:FDR's Court-Packing Plan, 81 Am Pol Sci Rev 1139 (1987).

16 Confidence in Institutions, available online at <http://www.gallup.com/poll/indieators/ indconfidence.asp> (visited Feb 23, 2001).

17 Id.

18 Over the past ten years, the percentage of respondents who indicated that they had a 
decisions ranging from affirmative action to abortion to civil rights to religion.

Bush v Gore lias not changed those overall numbers significantly. According to the Gallup poll, 59 percent of adults in January 2001 approved of the way the Supreme Court was handling its job, down only slightly from 62 percent in late August $2000 .^{19}$ While the Court's overall approval ratings have barely changed, however, the partisan composition of those numbers may be cause for concern. Approval of the Supreine Court among Republicans jumped from 60 percent in August 2000 to 80 percent by January 2001; among Democrats, that number fell from 70 percent in August to 42 percent in January. ${ }^{20}$ But what inay be inost inportant is independents; there the Court's approval ratimgs dropped marginally from 57 to 54 percent. ${ }^{2 .}$ While it is too early to tell whether this partisan split in attitudes toward the Court will undermme the Court's legitimacy, I think it more likely that the drop in Democratic opimons toward the Court will prove to be a temporary blip, for the reasons that follow.

\section{LEGITIMACY AS HISTORY}

A second way to approach the question of legitimacy would be to compare Bush $v$ Gore to other listorical periods in which the Court's authority has come into question. If the Court's actions today were similar m significant ways to earlier moments of cliallenge to judicial legitimacy, then we might predict that the changes in the immediate

\footnotetext{
"great deal" or "quite a lot" of confidence averages to 45.8 percent, with a low of 39 percent, and a high of 50 percent. Id.

19 Wendy W. Simmons, Election Controversy Apparently Drove Partisan Wedge into Attitudes Towards Supreme Court, available online at <http://www.gallup.com/poll/releases/ pr010116.asp> (visited Feb 23, 2001).

20 Id.

2I Id. A tentative study of public opinion on the Supreme Court and the 2000 election conducted by political scientists reaches similar conclusions. They find that a majority of Americans approve of the Court's decision and believe it to have been fair. They also find that Democrats are far more likely to disapprove of the Court's decision and to view it as unfair than Republicans. See James L. Gibson, Gregory A. Caldeira, and Lester K. Spence, The Supreme Court and the 2000 Presidential Election, unpublished manuscript, available online at <http://artsci.wustl. edu/ legit/research.html> (visited Apr 27, 2001). Another study by the same authors finds that the Court has not damaged its legitimacy with Bush $v$ Gore. After the Court's decision, they find that more than 80 percent of the public remams supportive of the Court, that nore than 75 percent believe the Court can be trusted, and that about 85 percent would obey the Court even if they disagreed with its decisions. The authors compared their data to 1987 and 1995 polls and found that, if anything, support among the public for the Court has increased. See James L. Gibson, Gregory A. Caldeira, and Lester K. Spence, The Legitimacy of the U.S. Supreme Court, unpublished manuscript, available onlime at <http://artsci.wustl.edu/ legit/research.html> (visited Apr 27,2001). As these political scientists conclude from the polling data, "support for the Court does not seem to have been depressed by its involvement in the 2000 presidential election." Id.
} 
polling data may augur a more sustained attack on the Court. Evaluating Bush v Gore im light of earlier historical periods, however, suggests that any sustained assault on the Court's legitimacy is unlikely to arise. The Court's authority lias come under serious question four times in our history: the Marsliall Court, the Taney Court's decision in Dred Scott, the Court's early resistance to the New Deal, and the Warren Court's figlt against segregation and its expansion of individual liberties. Close inspection of these periods show that they bear hittle resemblance to Bush v Gore.

The defining characteristic of several of these periods was the persistent, central role of the Court in the political disputes of the day. The New Deal period is perhaps the most obvious in this regard. In an effort to end the Great Depression, President Franklin Roosevelt and a Deinocratic Congress enacted economic regulatory legislation that sought to impose national solutions on the crisis. In cases such as A.L.A. Schechter Poultry Corp v United States" and Carter v Carter Coal $\mathrm{Co}^{23}$ the Court invalidated New Deal laws as beyond Congress's Commerce Clause power. These cases followed upon a series of decisions during the Progressive Era that also had restricted the scope of Congress's powers to regulate the econoiny." By the time of the 1936 presidential election, the Court liad struck down six federal laws that formed part of FDR's effort to bring about economic recovery. The Supreme Court came to be seen as one of the last obstacles. Similarly, during the Warren Court period, the Court not ouly decided Brown $v$ Board of Education, ${ }^{25}$ but also remained in the forefront of the public's attention with other desegregation cases."

In both periods, the Court intervened into the most pressing substantive issues of the day-econormic depression and race, among others-and did so repeatedly over a course of years. Even during the Marshall Court period, in which the decisions might be considered more structural-the existence of judicial review, Congress's Necessary and Proper Clause power, ${ }^{23}$ the Commerce Clause power ${ }^{2}$-than substantive, the Court remained at the center stage of national politics

295 US 495 (1935).

298 US 238 (1936).

See, for example, Hammer v Dagenhart, 247 US 251 (1918).

347 US 483 (1954).

26 Brown $v$ Board of Education ("Brown II"), 349 US 294 (1955); Bolling y Sharpe, 347 US 497 (1954); Cooper v Aaron, 358 US 1 (1958); Griffin v County School Board, 377 US 218 (1964); Green v County School Board, 391 US 430 (1968).

27 Marbury v Madison, 5 US (1 Cranch) 137 (1803).

$28 M^{\prime}$ Culloch v Maryland, 17 US (4 Wheat) 316 (1819).

29 Gibbons v Ogden, 22 US (9 Wheat) 1 (1824). 
for several years. Only in Dred Scott ${ }^{30}$ can the Court be said to have decisively acted only once to settle a national issue. In invalidating the Missouri Compromise, however, that one intrusion represented the Court's effort to end a divisive national debate that had been the central issue in Americau politics for several generations.

The nature of the Court's interference in these issues almost inevitably sparked a response by the other actors in the political system. In the case of the Marshall Court, it was Jefferson's muttered threats to defy judicial orders. ${ }^{31}$ With the Taney Court, it was Abraham Lincoln's attacks on Dred Scott and, ultimately, the coming of the Civil War. With the New Deal Court, President Roosevelt responded by campaigniug against the Court and introducing his famous Courtpacking plan. ${ }^{33}$ With the Warren Court, it was resistance throughout the southern states, criticism in Congress, and criticism from presidential candidates. ${ }^{34}$ The response of the political branches or the states demonstrates that the Court had acted in a manner that threatened its own legitimacy. Because the Court had sought to foreclose society (or parts of it) from using the lawmaking process to achieve certain ends, and because those ends were of such intense importance to the people, the chief if not only way for the people (or interest groups, if one prefers a public choice approach to the political process) to pursue their policy preferences was to attack the Court. In other words, the other pohitical actors had to undermine the Court's legitimacy as an institution so as to convince the electorate to support efforts to evade or overturn its decisions.

Contrast these periods with Bush $v$ Gore. In Bush $v$ Gore, the Court sought to resolve a narrow legal issue involving the selection of presidential electors. The question bears no constitutional implications for the resolution of any significant and ongoing social issues of today-abortion, race relations, education, social security, defense. The decision poses no bar to a society that seeks to use the democratic

30 Scott v Sanford ("Dred Scott"), 60 US 393 (1857).

31 For my own discussion of one instance during this period, see John C. Yoo, The First Claim: The Burr Trial, United States v. Nixon, and Presidential Power, 83 Minn L Rev 1435, 1451 (1999).

32 See, for example, The Dred Scott Decision: Speech at Springfield, Illinois, June 26, 1857, in Roy P. Basler, ed, Abraham Lincoln: His Speeches and Writings 354-65 (World 1946).

33 William E. Leuchtenburg, The Supreme Court Reborn: The Constitutional Revolution in the Age of Roosevelt 82-162 (Oxford 1995).

34 Such resistance prevented school desegregation from taking hold in the South for more than a decade after Brown. See Gerald Rosenberg, The Hollow Hope: Can Courts Bring About Social Change? 74-93 (Chicago 1991). Recent work suggests that the Warren Court did not act out of step with the political branches. See Lucas A. Powe, The Warren Court and American Politics 160-78 (Harvard 2000). 
process to resolve any pressing social problems. While the Democratic party has reason to be dissatisfied with the outcome of Bush v Gore, it has no interest in challenging the legal reasoning of the decision in the future. It is highly unlikely that the Court will remain a central player in future presidential election contests. Indeed, the Court's members were last involved in a disputed presidential election more than a century ago. Further, in Bush v Gore, the Court was not truly deciding a question of constitutional substance on a par with the scope of abortion rights or the national government's power to enforce civil rights. Instead, it was only clarifying the rules of the game for selecting the only federal official elected by the whole nation. It is difficult to conceive of a constitutional question that is more of a pure question of constitutional structure, rather than of substantive constitutional rights. Indeed, the Court perhaps was best suited, as a rational decisionmaker, to settle questions involving rules of constitutional process that may stalemate the other branches of government.

\section{LEGITIMACY AS IMPARTIALITY}

A third way to examine whether Bush v Gore is likely to undermine the Court's legitimacy is to look at current theories of the sources of the Court's authority. The Court itself has sought to give content to its "legitimacy" in Planned Parenthood of Southeastern Pennsylvania $v$ Casey. ${ }^{35}$ In refusing to overrule Roe $v$ Wade, ${ }^{3,5}$ a plurality explained that reversing its precedent would undermine the Court's legitimacy, which it saw as the very source of the judiciary's authority. "As Americans of each succeeding generation are rightly told, the Court cannot buy support for its decisions by spending money and, except to a minor degree, it cannot independently coerce obedience to its decrees." Thus, the judiciary's power is distinguished from the use of force or finances, which are the tools of the political branches. "The Court's power hes, rather, in its legitimacy, a product of substance and perception that shows itself in the people's acceptance of the Judiciary as fit to determine what the Nation's law ineans and to declare what it demands." Without the sword or purse, the Casey plurality believes, the Court's authority derives from the public's acceptance of its power to interpret the Constitution.

\footnotetext{
35505 US 833 (1992) (plurality opinion).

36410 US 113 (1973).

37 Casey, 505 US at 865.

38 Id.
} 
How does the Court maintain this legitimacy? According to the Casey plurality, the Court receives its public support by "making legally principled decisions under circumstances in which their principled character is sufficiently plausible to be accepted by the Nation.", In other words, only by acting in a manner that suggests that its decisions are the product of law rather than politics can the Court maintain its legitimacy. Therefore, the Court must adhere to settled precedent, lest the public believe that the Court is merely just another political actor. "[T]o overrule under fire in the absence of the most compelling reasou to reexamine a watershed decision would subvert the Court's legitimacy beyond any serious question." ${ }^{, 40}$ Without this legitimacy, the Court would be imable to perform its role as interpreter of the Constitution, which at times may require the Court to act against the popular will in favor of individual rights.

Leading social scientists appear to agree with the Casey plurality's notion of judicial legitimacy. The Court's institutional legitimacy both enlances the legitimacy of particular decisions and increases the voluntarily acceptance of unpopular decisions. "Valuable as it is, lowever, legitimacy is hard to come by. Political scientists have emphasized the limited ability of the federal courts to enforce their decisions, and hence lave turned to the Court's legitimacy as an explanation for compliance. The Court's standing is further complicated because it lacks any electoral basis for its legitimacy. ${ }^{43}$ The way to acquire this legitimacy, many scholars seem to believe, is for the Court to appear to act neutrally, ${ }^{44}$ objectively, ${ }^{45}$ or fairly ${ }^{46}$ by following standards of procedural justice or by makmg decisions that follow principled rules.

Thus, the question for judging the Court's legitimacy is to evaluate claims that the Rehnquist Court was so intent on achieving partisan ends in Bush v Gore that it violated or ignored its own guiding principles. Two claims are prominently made to suggest that Bush $v$

39 Id at 866.

40 Id at 867.

41 Tyler and Mitchell, 43 Duke L J at 723 (cited in note 11).

42 See, for example, Murphy and Tanenhaus, $84 \mathrm{Nw}$ U L Rev at 992 (cited in note 14).

43 Gregory A. Caldeira and James L. Gibson, The Etiology of Public Support for the Supreme Court, 36 Am J Pol Sci 635, 635 (1992).

44 Marshall, Public Opinion at 133 (cited in note 15) ("Justices are viewed as fair, neutral, and even-handed.").

45 Owen M. Fiss, Objectivity and Interpretation, 34 Stan L Rev 739, 744-45 (1982) (questioning "whether any judicial interpretation can achieve the measure of objectivity required by the idea of law").

46 Tyler and Mitchell, 43 Duke L J at 746 (cited in note 11) ("[T]he key factor affecting the perceived legitimacy of authorities is procedural fairness."). 
Gore was inconsistent with the Court's earher decisions. First, the Court was acting out of character when it exercised federal power to intervene in the core state function of running elections. Second, a Court that has criticized judicial "activism" suddenly interfered in an especially pohitical process, one fraught with partisanship, and imposed its own unappealable solution upon the problem. The rest of this Essay will examine whether these claims of judicial hypocrisy ring true.

Federalism has become the defining issue of the Rehnquist Court. To the extent that the current Court has changed American constitutional law, its activities in redefining the balance of power between the national government and the states will likely prove to be what the Rehnquist Court is best known for. Much of the Court's recent activity has been in the sphere of state sovereignty-protecting states as institutions from federal judicial power through state immunity from damages actions in federal court $t^{\text {th }}$ and from federal legislative power through anti-commandeering principles. Last Term's United States $v$ Morrison ${ }^{* 9}$ underscored yet another element of the Court's federalism project. In invalidating portions of the Violence Against Women Act, ${ }^{3,}$ Morrison indicates that the Court is serious about limiting national power itself, regardless of a law's effect on states as institutions. While the Court has inade some inportant decisions restricting Congress's powers to expand individual constitutional rights in ways that carmot be abrogated by states, ${ }^{\text {st }}$ Morrison declares the Court's firm intention to restore limits on Congress's basic power to regulate interstate cominerce as well."

47 See, for example, Alden v Maine, 527 US 706 (1999) (holding that the Eleventh Amend. ment gives states immunity from suits in state court arising under federal law issued pursuant to Congress's Article I powers); Seminole Tribe v Florida, 517 US 44 (1995) (holding that the previously established congressional power to abrogate state immunity is limited to implementation of the Fourteenth Amendment).

48 See, for example, Printz v United States, 521 US 898 (1997) (striking down a portion of the Brady Bill on grounds that it conscripted state officials to execute federal law); New York $y$ United States, 505 US 144 (1992) (overturning a law that required the states either to enaet radioactive waste legislation or take title to the waste).

49120 S Ct 1740 (2000).

50 Pub L No 103-322, $10 \$$ Stat 1941, codified at 42 USC $\$ 13981$ (1994).

51 See, for example, Kimel v Florida Board of Regents, 528 US 62 (2000) (holding that states were not subject to the Age Discrimination in Einployment Act under the Eleventh Amendment); College Savings Bank v Florida Prepaid Postsecondary Education Expense Board, 527 US 666 (1999) (limiting Congress's power to unilaterally abrogate states' sovereign immumity throngh legislation designed to remediate or prevent constitutional violations under Section 5 of the Fourteenth Amendment); City of Boeme v Flores, 521 US 507 (1997) (invalidating the Religious Freedom Restoration Act as impermissibly expanding the scope of Fourteenth Amendment protections).

52 While the Court in United States v Lopez, 514 US 549 (1995), struck down a law on Commerce Clause grounds, many commentators were unsure whether this was to be a one-time 
A principled adherence to federahsm, however, does not require the Court to refuse to review the presidential election procedures used by the states. Federahism does not create a free-fire zone where states may do anything they please. Rather, federalism is about the appropriate balance of power between federal and state authority, so that neither government abuses its own power at the expense of the rights of the people. ${ }^{53}$ By dividing power between the federal and state governments, and then subjecting each to the separation of powers, James Madison wrote in Federalist 51, "a double security arises to the rights of the people. The different governments will controul each other; at the same time that each will be controuled by itself."

This is nowhere truer than in the area of voting. The Constitution certainly accords substantial leeway to the states to manage voting in their own way. As we now know, Article II, Section 1 of the Constitution declares: "each State shall appoint, in such Manner as the Legislature Thereof May Direct, a Number of Electors." Nonetheless, our constitutional systein today permits substantial federal intervention into state elections. Congress, for example, has required states to use single-member districts for congressional elections since $1842 .{ }^{35}$ The Fourteenth and Fifteenth Amendments to the Constitution guarantee the individual right of each citizen to vote on an equal basis and prohibit states from attempting to discriminate against protected groups by denying them access to the voting booth. ${ }^{\text {s? }}$ Bush $v$ Gore's per curiain holding found that the Fourteenth Amendment's guarantee of equal treatment in voting apphed not just to access to the ballot box, but also to a state's treatment of a vote after it is cast. ${ }^{\text {ss }}$

Federal courts and the federal government have engaged in sweeping intervention into state voting procedures. In decisions such as Baker $v$ Carr $^{59}$ and Reynolds $v$ Sims, ${ }^{60}$ the Court established the principle of one-person, one-vote. In its recent redistricting cases, such as Shaw $v$ Reno, ${ }^{61}$ the Court has held that states cannot use race as a primary factor in drawing voting districts. Congress has also gotten into the game. Today, in many areas of the nation, the Voting Rights

event, given certain deficiencies in the federal law at issue there.

53 See John C. Yoo, The Judicial Safeguards of Federalism, 70 S Cal L Rev 1311, 1402-04 (1997).

54 Federalist 51 (Madison), in Jacob E. Cooke, ed, The Federalist 351 (Wesleyan 1961).

55 US Const Art II, $\$ 1$.

56 Act of June 25, $1842 \S 2,5$ Stat 491, codified at 2 USC $\$ 2 c$ (1994).

57 US Const Amend XIV-XV.

$58121 \mathrm{~S} \mathrm{Ct}$ at 530.

59369 US 186 (1962).

60377 US 533 (1964).

61509 US 630 (1993). 
Act of 1965 prevents states from changing any voting standard, practice, or procedure without the permission of the Attorney General or a federal court in Washington, D.C. Under this mix of federal laws and judicial precedents, the Court will hear claims that states have engaged in "vote dilution," where election procedures or redistricting essentially gives more political power to some districts over others."

Beyond the general federal involvement in state voting procedures, presidential elections specifically implicate a mix of federal and state laws. The Constitution overrides state constitutions and their allocation of functions by delegating to state legislatures, specifically, the power to establish the rules for choosing presidential electors. Federal law establishes the date on which the presidential election will be held in every state, it allows state legislatures to choose alternative inethods if a choice is not made, ${ }^{\infty}$ and federal law explains how Congress will count a state's electoral votes that undergo a challenge." While a state may use judicial methods to resolve these disputes, they inust proceed by rules enacted before the election (the essence of the Bush suit before the U.S. Supreme Court). Finally, Congress has established December 18 as the date that the electors must meet in each state and send their votes to Washington.

So federal judicial review of state election procedures is nothing new, not even to the Rehnquist Court. It is certainly not the direct threat to our federal system of government that some have claimed, unless they believe that national intervention into state electoral systems violates the basic structure of our federal systein of government. Indeed, the Court's intervention in the presidential election dispute was not completely without precedent. While it is true that states have the discretion to set the manner of the state's appointunent of presidential electors, electors are federal, not state, officials chosen in a federal, not a state, election. When states select officers that play a federal role, as the Supreme Court aumounced in U.S. Term Limits $v$ Thornton, they lave a reduced ability to interfere with their activities or method of selection. In Term Limits, for example, the Court rejected arguments that a state's constitutional power to control the "Times, Places, and Manner" of holding congressional elections al- 
lowed it to prevent mcumbents from appearing on the ballot. ${ }^{69}$ This suggests that the state's power over the manner of the selection of presidential electors cannot go far beyond procedural matters such as when and where an election is to be held. Once a state began to use procedures, as im Florida, that may have advantaged one candidate over another, federal principles justified judicial preservation of the integrity of the electoral process.

Even if federahism principles did not prevent the Court from resolving Bush v Gore, some may criticize the justices because of their intervention into a deeply pohtical dispute. If not by its deeds, certamly by its rhetoric, the Rehnquist Court has promoted the idea of judicial restraint. While yet another phrase that is often used but seldom defined, judicial restraint can be seen generally as a response to the countermajoritarian difficulty. ${ }^{70}$ Because judges are not elected and legislators are, judges should exercise such an undemocratic power as sparingly as possible-how sparingly and on what subjects, of course, remains the subject of great debate. "The last paragraph of the Bush v Gore per curiam genuflects to this ideal. "None are more conscious of the vital limits on judicial authority than are the members of this Court, and none stand more in admiration of the Constitution's design to leave the selection of the President to the people, through their legislatures, and to the political sphere."

Of course, the majority ran right into the political thickets anyway. Proponents of judicial restramt might have found the Court's interference surprising, if not wholly unjustified. The Court had available any number of opportunities to exercise Alexander Bickel's "passive virtues" ${ }^{, 33}$ to avoid deciding the case, including denying certiorari in the first Florida election case to come before it, ${ }^{74}$ or denying the stay and certiorari in Bush v Gore. Nonetheless, the Court invoked its duty to decide federal question cases as justification. According to the Court, " $[w]$ hen contending parties invoke the process of the courts, however, it becomes our unsought responsibility to resolve the federal

69 Id at 829.

70 For well-known efforts to define and grapple with the countermajoritarian difficulty, see generally Jesse H. Choper, Judicial Review and the National Political Process: A Functional Re. consideration of the Role of the Supreme Court (Chicago 1980); John Hart Ely, Democracy and Distrust: A Theory of Judicial Review (Harvard 1980); Alexander M. Bickel, The Least Dangerous Branch: The Supreme Court at the Bar of Politics (Yale $2 \mathrm{~d}$ ed 1986).

71 For a discussion and criticism of the leading theories, see Terri Jennings Peretti, In Defense of a Political Court 36-54 (Princeton 1999).

72 Bush v Gore, $121 \mathrm{~S} \mathrm{Ct}$ at 533.

73 Bickel, Least Dangerous Branch at 111-98 (cited in note 70).

74 Bush v Palm Beach County Canvassing Board, 121 S Ct 471 (2000) (per curiam). 
and constitutional issues the judicial system has been forced to confront." ${ }^{75}$ Unfortunately, this statement is so vague as to carry almost no meaning, as it encompasses any number of cases that the Rehnquist Court would be only too happy to dismiss on grounds of standing or the pohtical question doctrine.

Critics of Bush v Gore, however, should not have been surprised by the Court's lack of restraint. This Court has done everything but hide behind the passive virtues. It has reaffirmed the right to abortion ${ }^{\text {ts }}$ and has placed limits on religion in the public sphere. In the federalism area, it has invalidated a series of federal laws in order both to protect state sovereignty and to limit the powers of the national government. One of the laws, the Violence Against Women Act, passed Congress by large majorities in both houses of Congress. In the race area, the Court has invalidated affirmative action in federal contracting $^{85}$ and struck down redistricting that sought to maximize minority representation. ${ }^{81}$ On the First Amendment, the Court has invalidated federal laws so as to expand cominercial speech ${ }^{\mathrm{E}}$ and to protect indecent or pornographic material. ${ }^{\$ 1}$ It has risked confrontation with the pohtical branches by striking down federal laws solely on the ground that they violate the separation of powers. Hence, the Court has invalidated the Line Item Veto Act ${ }^{\text {st }}$ and reversed an effort to expand religious freedoms that the Court had cut back. ${ }^{\mathbb{s}}$ This Court has been anything but shy in flexing its powers of judicial review to intervene in some of the most contentious issues of the day.

What is important about the Court's recent track record is not just the frequency of the uses of judicial review, but their quality. Initially, the Marshall Court in Marbury v Madison grounded judicial review in the Court's umique function in deciding cases or controversies

\footnotetext{
Bush $v$ Gore, $121 \mathrm{~S} \mathrm{Ct}$ at 533.

See Lujan v Defenders of Wildlife, 504 US 555, 573-78 (1992).

Nixon $v$ United States, 506 US 224, 228 (1993).

Casey, 505 US 833.
}

Lee $v$ Weisman, 505 US 577, 592-93 (1992). The Court, however, also has sought to give religious groups an equal footing in its participation in government aid programs Mitchell v Helms, 530 US 793 (2000) (holding that taxpayer unoney could be used to buy computers and other instructional materials for religious schools); Agostini v Felton, 521 US 203 (1997) (allowing publicly paid teachers to be provided to parochial schools to assist disabled students with remedial, secular education).

80 Adarand Constructors, Inc v Pena, 515 US 200 (1995).

81 Shaw $v$ Reno, 509 US 630 (1993).

82 See, for example, 44 Liquormart, Inc v Rhode Island, 517 US 484 (1996).

83 See, for example, United States v Playboy Entertainmemt Group, 120 S Ct 1878, 1893 (2000); Reno v American Civil Liberties Union, 521 US 844 (1997).

84 Clinton v New York, 524 US 417 (1998).

85 Flores, 521 US 507. 
that arise under federal law. As Thomas Jefferson argued, this basis for judicial review leaves ample room for the coordinate branches of government to imterpret the Constitution in the course of performing their own constitutional functions. ${ }^{87}$ Under the Rehnquist Court, this himited vision of judicial review has steadily been supplanted by assertions of judicial supremacy - that the Supreme Court is not just an interpreter of the Constitution, but the interpreter of the Constitution."s To be sure, the Court's move toward claimmg that its readings of the Constitution were final, and that they bound the other branches, truly began with the Burger Court's decision in United States $v$ Nixon, ${ }^{89}$ if not before. ${ }^{\circ}$ Under the Rehnquist Court, however, the justices have rapidly expanded their claims to supremacy. In City of Boerne $v$ Flores, , the Court unanimously declared that Congress could not use its power to enforce Fourteenth Amendment rights inconsistently with the Court's interpretation of the scope of those rights. Several cases have followed that make clear the justices' intentions to stand by Flores's core holding."

Such assertions of judicial supremacy belie any notions that the Rehnquist Court generally has followed a course of restraint. If the Court is willing to go so far as to declare that its power to interpret the Constitution is supreme over the other branches, certainly it is no greater a step to intervene in a dispute about non-substantive, rarely-

865 US (1 Cranch) 137, 176 (1803). See also Robert Lowry Clinton, Marbury v. Madison and Judicial Review 15-17 (University Press of Kansas 1989); Christopher Wolfe, The Rise of Modern Judicial Review: From Constitutional Interpretation to Judge-Made Law 80-89 (Basic 1986).

87 See, for example, Letter from Thomas Jefferson to Abigail Adams, Sept 11, 1804, in Paul L. Ford, ed, 10 Works of Thomas Jefferson 89 n 1 (G.P. Putnam's Sons 1905).

88 For my account of this development, see John C. Yoo, Book Review, Choosing Justices: $A$ Political Appointments Process and the Wages of Judicial Supremacy, 98 Mich L Rev 1436, 145861 (2000).

89418 US 683 (1974). For sharp criticism of this vision of judicial review, see Michacl Stokes Paulsen, The Most Dangerous Branch: Executive Power to Say What the Law Is, 83 Georgetown L J 217, 228-38, 255-62 (1994).

90 Some might argue that the Court first proclaimed its supremacy in Cooper v Aaron, 358 US 1 (1958), in which the Court declared that not only were the Court's opinions the "supreme Law of the Land," but that the Court was "supreme in the exposition" of the Constitution. Id at 18. Cooper, however, was aimed not at the other branches of government, but at forcing state officials to follow federal interpretation of the Constitution. See Daniel A. Farber, The Supreme Court and the Rule of Law: Cooper v. Aaron Revisited, 1982 U IIl L Rev 387,398-403.

91521 US 507 (1997).

92 See, for example, Dickerson v United States, 530 US 428 (2000) (holding Congress could not alter Miranda rights); Morrison, $120 \mathrm{~S} \mathrm{Ct} 1740$ (striking down the Violence Against Women Act); Kimel, 528 US 62 (preventing enforcement of the ADA against the states); Florida Prepaid Postsecondary Education Expense Board v College Savings Bank, 527 US 627 (1999) (holding Congress cannot abrogate state sovereign immunity from patent claims). 
used election procedures. Nor should critics of Bush $v$ Gore express dismay at the role the Court took upon itself in settling the presidential election dispute. Claims to judicial supremacy bespeak an arrogance that the Court lias a special role in the American political system, one borne not just out of its unique function in deciding cases or controversies, but out of some vague vision of itself as a final resolver of national issues. The justices, in other words, have truly conne to beheve in Justice Jackson's famous apliorisin that "[w]e are not final because we are infallible, but we are infallible only because we are final. ${ }^{93}$ Judicial supremacy has led the Court to view itself not only as the final interpreter of the Constitution, but also-since as Tocqueville noted, many poitical disputes in America eventually become legal ones-as the nation's final oracle on divisive national controversies.

This should have been apparent froin a close reading of Casey, the same case in which the plurality of Justices O'Connor, Kennedy, and Souter articulated their theory about the Court's own legitimacy. In declaring its refusal to overrule Roe $v$ Wade, the plurality equated the Court's power to interpret the Constitution with the authority to end divisive national controversies. It is worth quoting the plurality on this point:

Where, in the performance of its judicial duties, the Court decides a case in such a way as to resolve the sort of intensely divisive controversy reflected in Roe and those rare, comparable cases, its decision has a dinension that the resolution of the normal case does not carry. It is the dimension present whenever the Court's interpretation of the Constitution calls the contending sides of a national controversy to end their national division by accepting a common mandate rooted in the Constitution."

As Casey suggests, the Court's drive for supremacy reveals an image of itself as a great liealer of national divisions. One need only have replaced "abortion" with "presidential election" to see that the Court would intervene in Bush v Gore.

By reviewing the case, the Supreine Court believed that it could finally bring an end to the destructive partisan struggle over the presidential election, and could do it in a way that would allow the nation to accept the final winner's own legitimacy. A look at the alternatives shows that events threatened to spiral out of control. Any Bush victory that resulted from the intervention of the Florida legislature or Congress, while legal, would undoubtedly have been questioned as 
driven purely by partisanship. On the other hand, Republicans would have rejected a Gore victory as the result of ever-changing, subjective dimple-counting practices of a few local party hacks or the decisions of a political state judiciary. All of the institutions that could control the outcome of the election - the legislature, the Florida Secretary of State, the Florida Supreme Court, the local election officials and Congress - were subject to charges of partisan bias. Although these institutions are popularly elected, their partisan nature might have allowed the election process to drag on-certainly both Republicans and Democrats demonstrated a willingness in Florida to fight on through each stage of the electoral college process. No doubt the Court believed that only it could intervene so as to bring the national election controversy to an end im a maimer that would be accepted by the nation, as indeed it has been."

This is not to say that the precise reasoning of the per curiam was utterly correct. I vastly prefer the theory put forward by the Chief Justice's concurrence: Florida's judiciary had so re-written the state's electoral laws that it had violated Article II's delegation of authority to the state legislatures to choose the method for selecting presidential electors. ${ }^{96}$ Indeed, the per curiam's sudden introduction of the December 12 cutoff date for a remedy-based on the assumption that the Florida legislature intended to adopt the safe harbor date for the selection of presidential electors provided for by 3 USC $\S 5-$ makes almost no sense at all unless read in light of the concurrence's structural analysis. What all of this goes to show, rather, is that in deciding Bush $v$ Gore the Court was not acting in a hypocritical or partisan fashion. Instead of contradicting its own cases on federalism or judicial restraint, the Court acted in keeping with the general trends of its own jurisprudence over the last decade. The Court's declaration of its role in Casey might even have made the justices' intervention in the election dispute somewhat predictable. Consistency of action constitutes a core feature of theories about the Court's legitimacy. The Court's adherence to its own principles inakes it all the more difficult, then, to conclude that Bush v Gore will undermine the judiciary's legitimacy.

95 On December 10, CNN reported that 61 percent of those polled preferred that the United States Supreme Court make the final decision on the selection of the next President, as compared to 17 percent who believed Congress should make the final decision, 9 percent who beheved that the Florida State Supreme Court should make the final decision, and only 7 percent who beheved the Florida legislature should make the final decision. See <http://www.cnn.com/2000/ALLPOLITICS/stories/12/10/cnn.poll> (visited Feb 24, 2001).

96 Bush v Gore, $121 \mathrm{~S} \mathrm{Ct}$ at 533-35. 


\section{CONCLUSION}

Many in legal academia welcomed Planned Parenthood $v$ Casey when it first appeared." I would hazard a guess that many of these same supporters of Casey have not rushed to embrace Bush v Gore. Yet, Casey contamed the seeds - the claims to judicial supremacy and the aggrandized notions of the Court's role in American society - that would blossom in Bush $v$ Gore. Indeed, one can even view the emergence of the per curiam opmion-clearly the work of Justices Kennedy and O'Comior - as evidence of an ultimately failed effort to rebuild the coalition that had produced the unprecedented Casey plurality. As in Casey, in Bush v Gore the Court sought to end a national debate that it feared was tearing the country apart. In fact, the Court's chances of success were much higher $\mathrm{m}$ the presidential contest, im which the political system needed a final decision on process rules, than in the abortion debate, which has remamed a controversial issue of intense importance to many Americans for decades. It seems that if the Court could intervene into such a contentious political debate as abortion, and survive with its legitimacy more or less intact, then it could safely bring the election dispute to a final conclusion as well.

97 See, for example, Kathleen Sullivan, The Supreme Court, 1991 Term Forward: The Justices of Rules and Standards, 106 Harv L Rev 22, 24-25 (1992). 


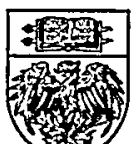

HeinOnline -- 68 U. Chi. L. Rev. 7922001 